\title{
Su Kullanıcılarına ve Birlik Çalışanlarına Göre Bursa Sulama Birliklerinin Performansının Değerlendirilmesi
}

\section{Ömer Tarık Ersöz ${ }^{1}$ Gökhan Çamoğlu' ${ }^{2 *}$}

\author{
${ }^{1}$ Çanakkale 18 Mart Üniversitesi Ziraat Fakültesi Tarımsal Yapılar ve Sulama Anabilim Dalı \\ ${ }^{2}$ Çanakkale 18 Mart Üniversitesi Ziraat Fakültesi Tarımsal Yapılar ve Sulama Bölümü \\ *Sorumlu yazar: camoglu@ comu.edu.tr \\ ${ }^{1}$ https://orcid.org/0000-0002-2659-501x, ${ }^{2}$ https://orcid.org/0000-0002-6585-4221
}

Geliş Tarihi: 13.03.2020

Kabul Tarihi: 02.07.2020

\section{Öz}

Sulama birliklerinin işleyişinin değerlendirilmesinde, performans göstergelerinin yanı sıra suyu temin edenler ile su kullanıcılarının da görüşleri de önem arz etmektedir. Bu nedenle çalışmada, Bursa ili sınırlarında faaliyet gösteren on adet sulama birliğinin işletme alanlarında tarımsal faaliyet gösteren çiftçiler ve birlik çalışanları ile 2019 yılında gerçekleştirilen anket sonuçlarına göre birliklerin performanslarının değerlendirilmesi amaçlanmıştır. Çiftçilerle yapılan anketlerin sonuçlarına göre, katılımcıların en temel sorunlarının, sulama ücretlerinin yüksek olması, kanal sonlarında bulunan çiftçilerin suya ulaşmakta güçlük çekmesi ve drenaj yetersizliği olduğu belirlenmiştir. Sulama birliklerindeki personeller ile yapılan anketlere göre; genel olarak, birliklerin bakım onarım faaliyetlerini yeterli düzeyde gerçekleştirememesi, zamanında yeterli düzeyde tahsilat yapılamaması ve personelin hak ve sorumluluklarında oluşan bazı belirsizlikler gibi sorunların olduğu saptanmıştır. Daha sağlıklı bir sulama yönetimi için izleme ve değerlendirme çalışmaları devam etmeli ve tespit edilen sorunlar çözüme kavuşturulmalıdır.

Anahtar Kelimeler: Anket, memnuniyet, sulama birliği, su kullanıcısı

\section{Performance Evaluation of Bursa Irrigation Association according to Water Users and Association Employees \\ Abstract}

In evaluating the functioning of irrigation associations, besides performance indicators, opinions of the water suppliers and water users are also important. Therefore, in the study, it is aimed to evaluate ten irrigation associations operating in Bursa province according to the results of the survey conducted with farmers and association workers. According to the results of the surveys conducted with farmers, the main problems of the participants were high irrigation costs, difficulty in obtaining the water for the ones at the end of the canal and insufficient drainage. According to the surveys conducted with the employees in irrigation associations; in general, it was found that there were problems such as inadequate maintenance and repair activities, inadequate fee collection and some uncertainties in the rights and responsibilities of employees. Monitoring and evaluation studies should continue for a healthier irrigation management and the identified problems should be resolved.

Keywords: Survey, satisfaction, irrigation association, water user

\section{Giriş}

Sulama şebekelerinin önemli bir kısmı işletme ve bakım eksikliğinden oluşan sorunlardan dolayı yeterli verimi sağlayacak düzeyde çalışamamaktadır. Çiftçiler sulamayı genelde bitki gözlemlemelerine göre yapmakta, uygulamada ihtiyaç duyulan sulama suyu miktarı ve sulama sıklığı teknik bir kritere dayanmamaktadır. Çiftçilerden toplanan su ücretlerinin kullanılan su miktarına göre alınmaması aşıı su kullanımına yol açmaktadır (Uçan ve Boz, 2005). Gerçekleştirilen bu bilinçsiz sulamalar, her yıl belirli bir tarım alanının, ürün yetiştirilmesi mümkün olmayan verimsiz topraklar haline gelmesine sebep olmaktadır. Bu nedenle, toprak ve su kaynaklarının etkin kullanımı ve sulama işletmeciliğinin amacına ulaşıp ulaşmadığının belirlenmesi için sulama birliklerinde performansın değerlendirilmesi ve mevcut durumun belirlenmesi oldukça önemlidir. Gerçekleştirilen bu çalışmalar, sistemin genel durumunu değerlendirmek, sistemin işleyişini iyileştirmek, belirlenen hedefler doğrultusunda sistemi değerlendirmek, sistem performansını diğerleri ile karşılaştırmak ve zamana göre performans değerlendirmesi için yapılmaktadır. 
Toprak ve su kaynaklarının rasyonel bir biçimde geliştirilmesi ve kullanımı tarımsal üretimin artırılmasında tek başına yeterli olamamaktadır. Yüksek verimli, başarılı ve sürekli bir sulu tarımın gerçekleşmesi, iyi bir toprak etüdü, bölgesel şartlara uygun bitki deseni seçilmesi, sulama proje alanı büyüklüğünün rasyonel biçimde belirlenmesi, sulama suyunun randımanlı kullanılması, bilgili toprak idaresi yapılması, şartlara uygun drenaj sistemlerinin uygulanması ve devamlılığının sağlanması ve etkin bir çiftçi çalışmasıyla mümkün olabilmektedir (Çiftçi ve ark., 1995).

Mevcut suyun en iyi şekilde kullanılması, şebekelerde performansın yükseltilmesi açısından önemlidir (Süheri, 2004). Ülkemizde birçok sulama şebekelerinde benzer sulama sorunları bulunmaktadır. $\mathrm{Bu}$ sebeplerle hem çiftçinin sulama gereksinimlerinin karşılanabilmesi hem de işletmecilik sorunlarına çözüm getirilmesi tarımsal üretimde verimliliği ve istihdamı artıracak, sosyal ve ekonomik açıdan büyük oranda olumlu yönde bir etki sağlayacaktır.

Sulama birliği yönetiminin amaçları bazı çiftçilerin istekleri ile uygun düşmeyebilir. Çünkü işletmeciler eşit, adil su sağlama ve suyun kıt olduğu yerlerde verimli bir su dağıtımını sağlamak isterler. Suyun düzenli dağıtılması için işletmeci çiftçilere bazı kurallar koymak zorundadır. $\mathrm{Bu}$ durum, su dağıtım kurallarının zorla uygulanmasını gerektirir (Süheri, 2004).

Hizmet veren sulama birlikleri ve hizmet alan su kullanıcıları arasındaki iletişim önemlidir. İletişim ne kadar kuvvetli olursa o kadar kontrollü bir yönetim ve sorunsuz hizmet sağlanmış olacaktır. $\mathrm{Bu}$ nedenle, bunu anlamak için bazı anket çalışmalarına ihtiyaç duyulmaktadır. Ülkemizde de farklı bölgelerde sulama birliklerinin performanslarını anket yoluyla değerlendiren çalışmalara (Ceylan ve Gülçubuk, 1995; Beyribey ve ark., 1997; Güvercin ve Boz, 2003; Kıymaz, 2006; Demir, 2008) sıkça rastlanmaktadır. Ancak, söz konusu çalışmaların sonuçları yıldan yıla değiş̧iklik göstermektedir. İzleme ve değerlendirme çalışmalarının yapılmasında sürekliliğin sağlanması önemlidir. Bu kapsamda çalışmada, Bursa ili sınırlarında faaliyet gösteren sulama birliklerinin (İznik Keramet, İznik Merkez, İznik Ova Köyleri, Bursa, Demirtaş, Yenişehir, Nilüfer, Uluabat, Karacabey ve Mustafakemalpaşa) faaliyetleri, su kullanıcıları ve birlik personelleri ile yapılan anket sonuçlarına göre karşılaştırmalı olarak değerlendirilmiştir.

\section{Materyal ve Yöntem}

Bu çalışmada, Bursa'da faaliyet gösteren on adet sulama birliği (SB) ele alınmıştır (Çizelge 1). Çalışmada materyal olarak, bu birliklerde tarımsal faaliyet gösteren çiftçiler ile birlik çalışanlarına uygulanmış anket soruları kullanılmıştır.

Çizelge 1. Sulama birliklerine ilişkin bazı bilgiler

\begin{tabular}{|c|c|c|c|c|c|}
\hline Sulama Birliği & $\begin{array}{l}\text { İşletme Alanı } \\
\text { (ha) }\end{array}$ & $\begin{array}{l}\text { Devredild } \\
\text { iği Yil }\end{array}$ & Su Dağıtım Sistemi & Su Kaynağ 1 & $\begin{array}{c}\text { Sulama } \\
\text { Ücreti } \\
\text { Hesapla } \\
\text { ma } \\
\text { Yöntemi }\end{array}$ \\
\hline $\begin{array}{c}\text { İznik Gölü } \\
\text { Keramet }\end{array}$ & 2798 & 1997 & Kanalet/pompaj & İznik Gölü & $\mathrm{TL} \mathrm{da}^{-1}$ \\
\hline İznik Ova Köyleri & 4736 & 2005 & Kanalet/pompaj & İznik Gölü & $T L \mathrm{da}^{-1}$ \\
\hline İznik Merkez & 2200 & 2005 & Kanalet/pompaj & İznik Gölü & $T L \mathrm{da}^{-1}$ \\
\hline Karacabey & 16683 & 1996 & Kanalet/Pompaj & Manyas Gölü & $T L \mathrm{da}^{-1}$ \\
\hline Uluabat & 6344 & 2003 & Kanalet/Pompaj & Uluabat Gölü & $T L \mathrm{da}^{-1}$ \\
\hline Mustafakemalpaşa & 20271 & 1997 & Kanalet/Cazibe+Pompaj & $\begin{array}{c}\text { Musfatakemalpaş } \\
\text { a Çayı }\end{array}$ & $\mathrm{TL} \mathrm{da}^{-1}$ \\
\hline Yenişehir & $5020+11645$ & 2013 & Kapalı/Cazibe+Pompaj & $\begin{array}{c}53 \text { Adet YAS } \\
\text { Kuyusu + } \\
\text { Boğazköy Baraj1 }\end{array}$ & $\mathrm{TL} \mathrm{da}^{-1}$ \\
\hline Bursa & 1816 & 2000 & Kanalet/Cazibe & Gölbaşı Baraj1 & $T L \mathrm{da}^{-1}$ \\
\hline Demirtaş & 1510 & 2007 & Kanalet/Cazibe & Demirtaş Baraj & $T L d^{-1}$ \\
\hline Nilüfer & 2224 & 2013 & Kapal1+Kanalet/Cazibe & $\begin{array}{c}\text { Hasanağa Barajı + } \\
\text { Çalı ve Kayapa } \\
\text { Göletleri }\end{array}$ & $\mathrm{TL} \mathrm{da}^{-1}$ \\
\hline
\end{tabular}


Anket çalışmalarında amaçlı örnekleme yöntemi kullanılmıştır. Bunun için her sulama birliğinden 50 ile 100 kişi arasında su kullanıcısı (çiftçiler) tesadüfi olarak seçilmiştir. Birlik personellerinin ise tamamı ile anket yapılmıştır. Çiftçiler ile yapılan anketler birlik bazında, personeller ile yapılanlar ise tüm birlikler için değerlendirmeye tabi tutulmuştur.

Gerekli verilerin toplanması için hazırlanan ankette yer alan sorular, çiftçiler ve birlik personellerinin karşılaştı̆̆ çeşitli sorunları ve memnuniyet düzeylerini belirlemeye yöneliktir.

Anketlerden elde edilen verilerin değerlendirilmesi aşamasında, birlik personellerine ve çiftçilere uygulanan anket sonuçları soru başlıklarına göre değerlendirilmiştir. Benzer sorular hem personellere hem de çiftçilere sorularak ayrı ayrı ele alınmıştır. Sorulara göre ve genel olarak çiftçiler ile personellerin konulara yaklaşımları değerlendirilmiştir.

\section{Bulgular ve Tartışma \\ Çiftçi Gruplarına İlişkin Genel Bilgiler \\ Yaş Aralı̆̆ı}

Sulama birlikleri işletme alanlarındaki çiftçiler ile yapılan anket verilerine göre hangi yaş grubuna ait kitlenin ağırlıklı olarak tarımsal faaliyet gösterdiği Çizelge 2'de verilmiştir. Buna göre; tarımsal faaliyet gösteren bireyler 46-65 yaş gruplarında yoğunluk göstermekte ve genç nüfusun tarımdan uzak olduğu fark edilmektedir.

Sivük (2010) su kullanım davranışları üzerine bir araştırma kapsamında üreticilerin yaş aralığını 4 gruba ayırmış ve üreticilerin \%47,9'u 50 yaş üstü, \%45,6'sı 35-49 ve \%6,5'i ise 20-34 yaş grubunda yer aldığını belirtmiştir. Söz konusu çalışmada da benzer sonuçlar göze çarpmaktadır.

Çizelge 2. Sulama birliklerine göre çiftçilerin yaş aralıklarının oransal dağılımı (\%)

\begin{tabular}{ccccc}
\hline Sulama Birliği & $\mathbf{1 8 - 3 0}$ & $\mathbf{3 1 - 4 5}$ & $\mathbf{4 6 - 6 5}$ & 66 ve Üzeri \\
\hline İznik Gölü Keramet & 5 & 25 & 63 & 7 \\
İznik Ova Köyleri & 5 & 33 & 56 & 6 \\
İznik Merkez & 6 & 38 & 49 & 7 \\
Karacabey & 4 & 29 & 61 & 6 \\
Uluabat & 4 & 36 & 57 & 3 \\
Mustafakemalpaşa & 5 & 38 & 52 & 5 \\
Yenişehir & 6 & 30 & 60 & 4 \\
Bursa & 4 & 33 & 61 & 2 \\
Demirtaş & 7 & 31 & 59 & 3 \\
Nilüfer & 5 & 36 & 56 & 3 \\
\hline Ortalama & 5 & 33 & 57 & 5 \\
\hline
\end{tabular}

Genç nüfusun tarım dışında diğer meslek gruplarına yönelmeleri, ayrıca 66 yaş ve üzeri grupta sağlık ve emeklilik nedenlerinde dolayı tarımsal uğraş göstermedikleri ya da çok az tarımsal faaliyet gösterdikleri görülmektedir.

\section{Öğrenim Durumu}

Sulama birliklerine ait işletme alanlarındaki çiftçiler ile yapılan anket verilerine göre bireylerin eğitim düzeylerine ilişkin elde edilen veriler Çizelge 3 'te verilmiştir. Eğitim düzeyi ilkokul ve ortaokul olan çiftçilerin yüzdelerinin ortalamaları sirasıyla $\% 52$ ve $\% 39$ olup tüm kat1lımcıların \%91'ini kapsamaktadır. Lise ve üzeri eğitim seviyesindeki çiftçiler ise katılımcıların \%9'unu oluşturmaktadır.

Sulama birliklerine ilişkin çiftçilerin öğrenim düzeylerinin oransal dağılımına göre tarımsal faaliyet gösteren bireylerin ağırlıklı olarak ilk ve ortaokul düzeyinde oldukları görülmektedir. Çizelge 2 'de sunulan veriler ile eğitim düzeyleri birlikte değerlendirildiğinde, 46 ve üzeri yaş grubunun ve eğitim düzeyi ilkokul ve ortaokul seviyesinde yoğunluk kazanmasının başlica sebebi olarak, bu gruplardaki çiftçilerin kendi dönemlerinde eğitim anlayışından uzak ve aile büyükleri ile beraber tarım ağırlıklı olarak kırsalda yaşamış olmaları sayılabilir. 
Çizelge 3. Sulama birliklerine ilişkin çiftçilerin öğrenim düzeylerinin oransal dağılımı (\%)

\begin{tabular}{ccccc}
\hline Sulama Birliği & İlkokul & Ortaokul & Lise & Üniversite \\
\hline İznik Gölü Keramet & 43 & 48 & 8 & 1 \\
İznik Ova Köyleri & 47 & 43 & 9 & 1 \\
İznik Merkez & 45 & 49 & 4 & 2 \\
Karacabey & 56 & 38 & 5 & 1 \\
Uluabat & 61 & 32 & 6 & 1 \\
Mustafakemalpaşa & 59 & 32 & 7 & 2 \\
Yenişehir & 58 & 35 & 5 & 2 \\
Bursa & 66 & 27 & 6 & 1 \\
Demirtaş & 48 & 41 & 9 & 2 \\
Nilüfer & 42 & 46 & 10 & 2 \\
\hline Ortalama & 52 & 39 & 7 & 2 \\
\hline
\end{tabular}

\section{Arazi Varlı̆̆ı}

Çalışma alanında bulunan sulama birliklerinde tarımsal faaliyet gösteren çiftçilerin arazi varlıklarına ilişkin veriler Çizelge 4 'te gösterilmiştir.

Çizelge 4. Anket sonuçlarına göre çiftçilerin oransal arazi miktarları (\%)

\begin{tabular}{cccccc}
\hline Sulama Birliği & $\mathbf{1 - 1 0}$ da & $\mathbf{1 1 - 2 0 ~ d a}$ & $\mathbf{2 1 - 3 0}$ da & $\mathbf{3 1 - 4 0}$ da & 41 da ve Üzeri \\
\hline İznik Gölü Keramet & 9 & 69 & 11 & 7 & 4 \\
İznik Ova Köyleri & 9 & 37 & 46 & 5 & 3 \\
İznik Merkez & 11 & 42 & 42 & 3 & 2 \\
Karacabey & 12 & 16 & 28 & 27 & 17 \\
Uluabat & 10 & 27 & 29 & 19 & 15 \\
Mustafakemalpaşa & 11 & 29 & 21 & 21 & 18 \\
Yenişehir & 19 & 45 & 21 & 9 & 6 \\
Bursa & 20 & 48 & 21 & 9 & 2 \\
Demirtaş & 19 & 49 & 26 & 9 & 2 \\
Nilüfer & 18 & 53 & 19 & 7 & 3 \\
\hline Ortalama & 14 & 41 & 26 & 11 & 8 \\
\hline
\end{tabular}

Buna göre; arazi büyüklüklerinin 11-20 da ile 21-30 da olarak belirtilen aralıkta daha yoğun toplandığ görülmektedir. Meyve yetiştiriciliğinin yoğun olduğu ve çok yıllık bitki yetiştiriciliği yapılan işletme alanlarına sahip (İznik Gölü Keramet, İznik Ova Köyleri, İznik Merkez, Bursa ve Demirtaş) sulama birliklerinde parsel büyüklükleri ağırlıklı olarak 11-30 dekar aralığındadır. Tek yıllık bitki yetiştiriciliği yapılan işletme alanlarına sahip (Karacabey, Uluabat ve Mustafakemalpaşa) sulama birliklerinde ağırlıklı olarak 31 dekar ve üzeri parsel büyüklüklerinde olacak şekilde dağılım göstermiştir.

\section{Sulama Yöntemi}

Çalışma alanında çiftçiler tarafından uygulanan sulama yöntemlerine ait bilgiler Çizelge 5 'de verilmiştir. Buna göre; meyve üretiminin yoğun olduğu bölgelerde su kaybının en yüksek ve bunun neticesinde randımanın en düşük olduğu yöntem yüzey sulama yönteminin ağırlıklı olduğu görülmektedir.

Bahsi geçen alanlarda damla sulama ve yağmurlama sulama yöntemleri azınlıkta tercih edilmektedir. Su kaybının düşük randımanın yüksek olduğu sulama yöntemleri ise sebze, hububat, yem bitkisi gibi tek yıllık ürün yetiştiriciliği yapılan alanlarda daha fazla tercih edilmektedir.

Açık kanalet sulama sistemine sahip sulama birliklerinde damla sulama ve yağmurlama sulama yöntemlerinde çiftçiler basınç elde etmesi gerektiğinden uygulamada ekstra enerji gideri oluşturmakta ve basınç sağlama işlemi üretim maliyetinin artmasına sebep olmaktadır. Üretime yansıyan enerji giderinden dolayı açık kanalet sistemine sahip sulama birliklerinde çiftçiler yüzey sulamayı diğer sulama yöntemlerine göre daha fazla tercih etmektedirler. Kapalı borulu sisteme sahip olan sulama birliklerinde ise çiftçiler tarafindan en yaygın kullanılan sulama yöntemi damla ve yağmurlama sulama olmaktadır. 
Çizelge 5. Anket sonuçlarına göre uygulanan sulama yöntemleri (\%)

\begin{tabular}{cccccc}
\hline Sulama Birliği & Yüzey & Yağmurlama & Damla & Yüzey ve Yağmurlama & Yüzey ve Damla \\
\hline İznik Gölü Keramet & 39 & 15 & 12 & 13 & 21 \\
İznik Ova Köyleri & 37 & 13 & 25 & 12 & 13 \\
İznik Merkez & 38 & 15 & 22 & 11 & 14 \\
Karacabey & 29 & 28 & 15 & 17 & 11 \\
Uluabat & 32 & 18 & 11 & 20 & 19 \\
Mustafakemalpaşa & 26 & 31 & 21 & 10 & 12 \\
Yenişehir & 15 & 22 & 40 & 12 & 11 \\
Bursa & 41 & 11 & 15 & 15 & 17 \\
Demirtaş & 45 & 17 & 13 & 8 & 11 \\
Nilüfer & 21 & 22 & 40 & 6 & 15 \\
\hline Ortalama & 32 & 19 & 21 & 13 & \\
\hline
\end{tabular}

\section{Çiftçiler ile Yapılan Anketlere İlişkin Değerlendirmeler}

Çiftçiler ile gerçekleştirilen anket çalışması sonuçlarının değerlendirmeleri evet cevaplarının dağılımı Çizelge 6'da oransal olarak belirtilmiştir. Çiftçilere genel olarak aldıkları eğitimler ve sulama birliklerinin işleyişi hakkında 13 soru ve bir de açık uçlu soru olmak üzere toplam 14 soru yöneltilmiştir.

Soru 1: Sulama birlikleri işletme sahasında bulunan çiftçilere anket sorusu olarak üretimini gerçekleştirdikleri bitkinin su tüketimi hakkında bilgi sahibi olma durumu sorulmuştur. Ankete katılan çiftçilerin üretimini gerçekleştirdikleri bitki için su tüketimi hakkında \%41 (evet) oranında bilgi sahibi olduğu sonucu ortaya çıkmıştır. Bitki su tüketimi hakkında bilgisi olan çiftçiler bu bilgiyi, uzun yıllar boyunca tarımsal faaliyet gerçekleştirmeleri sonucu edindiklerini belirtmişlerdir. Ayrıca bitkinin ne zaman sulanacağına bitkiyi gözlemleyerek karar verdiklerini vurgulamışlardır.

Soru 2: Çiftçilere uygulamakta oldukları sulama yöntemi hakkında yeterli bilgiye sahip olma durumları (uygulanan yöntemler ile sulamanın yeterliliği, azlığı ya da fazlalığı ile meydana gelebilecek sorunlar vb.) sorulmuş elde edilen sonuca göre, ortalama \%64'ü (Evet) uyguladıkları sulama yöntemleri hakkında yeterli düzeyde bilgi sahibi olduklarını belirtmiştir. Sulama birliklerine göre verilen cevapların birbirine oldukça yakın olduğu görülmektedir. Uygulamakta oldukları sulama yöntemlerinde çiftçiler sahip oldukları bilgiyi, tarım ile uğraşan büyüklerinden ve diğer çiftçilerden edindiklerini belirtmişlerdir. Ayrıca, bunu yıllarca tarımsal faaliyet sürdürmelerinden dolayı yeterli seviyede tecrübe edinmelerine ve teknoloji ile bilgiye ulaşmanın kolaylaşması gibi durumlara bağlamışlardır. Ayrıca, çiftçilerin ilk iki soruda bitki su tüketimi ve sulama yöntemleri konularında verdikleri cevaplara göre, sulama birliklerinin bu konularda eğitim ve seminerler vermesi gerektiği söylenebilir.

Soru 3: Çiftçilerin sulama konusunda herhangi bir eğitime katılmış olma durumları sorulduğunda, ortalama olarak oldukça az bir kısmının (\%4) evet yanıtını verdiği görülmektedir. Katılım gösteren çiftçilerin ortalama 96'sı bir ya da birden fazla eğitime katılım sağlamadıkları anlaşılmıştır. Söz konusu çiftçiler, kendi bilgi düzeylerinin uygulamada yeterli olduğunu savunmakta ve yıllardır faaliyet gösterdikleri tarımsal üretim konusunda bahsi geçen öğrenimlerinin atalarından ve diğer çiftçilerin faaliyetlerine ilişkin gözlemlerden kazandıklarını belirtmektedirler. Görülmektedir ki sulama konusundaki eğitim eksikliğinin giderilmesi oldukça önem arz etmektedir. Bu durumda sulama birlikleri, suyu kaynaktan parsel başına iletmek dışında suyun parsel içerisine girdikten sonra da etkin şekilde kullanımına teşvik etmek ve suyun kullanımı konusundaki eğitimlere önderlik ederek çiftçilerin bu konuda yeterli seviyeye ulaşmasını sağlamaya yönelik çalışmalara ağırlık vermelidir.

Soru 4: $\mathrm{Bu}$ soruda, çiftçilerin sulama faaliyetlerini bilinçli olarak yapma konusundaki düşünceleri sorulmuştur. Çiftçilere yöneltilen bir önceki soruda (Soru 3) çiftçilerin sulama konusundan çok az düzeyde eğitimlere katılmış oldukları belirlenmiş ve burada ise ürün yetiştirirken bilinçli sulama yapıldığı düşüncesinin ağırlıklı olarak (\%64 Evet) hakim olduğu gözlenmiştir. Bu da çiftçilerde kendi kendine yetebilme düşüncesinin çok fazla olduğu ve bu düşüncelerini destekleyecek bir altyapı olmadığını göstermektedir.

Soru 5: Çiftçilerin sulama suyunu zamanında ve yeterli miktarda alabilme durumu ile ilgili verdikleri cevaplar incelendiğinde, en düşük değerlerin Uluabat (\%45) ve Demirtaş (\%46) sulama 
birlikleri, diğer taraftan ise genel ortalama $\% 75$ olduğu görülmektedir. Çiftçilerin yetiştiriciliğini yapmış olduğu tarımsal ürünün kaliteli ve verimli olabilmesi açısından temel ihtiyaç olan suyun bitki kök bölgesine zamanında ve yeterli miktarda verilmesi gerekmektedir. Bunun için, sulama birliği personeli arasında planlı görev dağılımı yapılması ve izleme değerlendirmenin yeterli düzeyde gerçekleştirilmesi şarttır. Çiftçinin zamanında ve yeterli miktarda sulama suyuna ulaşamaması bakım onarım çalışmalarının yetersiz olası, planlı su dağıtımının sağlanamaması, sulamaların yoğun olarak belirli bir dönemde toplanması ve su kaynağının yetersizliği gibi sebeplere bağlanabilir. Bunun dışında; bazı çiftçiler tarafından diğer çiftçilerin sulama haklarına saygı göstermeksizin kendi ürününü sulamak istemesi ve bu durumun birlik tarafından denetlenebilir olmamas1, birlik personeli ve yönetime yakın çiftçilere ayrıcalık gösterilmesi gibi nedenlerden dolayı çiftçilerin zamanında ve yeterli miktarda suya ulaşması zorlaşmaktadır. Sulama birliği yöneticileri sulama suyunu adil ve eşit dağıtarak, çiftçilerin sulama haklarını koruyarak sosyal huzuru bozacak davranışların önüne geçmeli ve disiplini elinde tutan yönetime sahip olmalıdır.

Soru 6: Sulama birlikleri işletme alanlarında faaliyet gösteren çiftçilere sulama hizmet bedeli hakkındaki görüşleri sorulmuştur. Verilen cevaplar incelendiğinde, sulama hizmet bedelini en az Uluabat \%68 (evet) ve en fazla da İznik Gölü Keramet \%91 (evet) sulama birliklerinde faaliyet gösteren çiftçiler yüksek bulmuştur. Genel olarak incelendiğinde, diğer sulama birliklerinde de çiftçiler tarafından sulama suyu ücretinin yüksek olduğu görüşü hakimdir. Bunun başlıca sebebi, pompaj sulama olarak hizmet veren tesislerin enerji giderlerinin ve tesislerin sürdürülebilirliği için gerekli olan bakım onarım giderlerinin yüksek olmasıdır. Ayrıca yönetim giderlerinin ve borçlu işletmelerde faizlerden kaynaklı giderlerinin artması da etkileyebilmektedir.

Soru 7: Birliklerin işletmekte oldukları tesislerde yeterince denetleme yapması izleme ve değerlendirme noktasında tesise ne kadar hakim olduğunu göstermektedir. Su iletim ve dağıtım kanallarında meydana gelen sorunların erken tespiti ve onarımı, kaçak sulamaların engellenmesi gibi birçok sorunun önüne geçmede oldukça önemlidir. Bu nedenle çiftçilere, birlik personelinin sulama tesisinin yeterince denetleme durumu sorulmuştur. Elde edilen sonuçlar incelendiğinde, sulama tesisinin denetimi konusunda en fazla olumlu görüş bildiren birliklerden ilk ikisinin Mustafakemalpaşa $(\% 91)$ ve Karacabey $(\% 90)$ sulama birlikleri olduğu görülmektedir. En düşük değer ise Demirtaş S.B.'de (\%55) elde edilmiştir. Düşük değere sahip sulama birliklerinde, genel olarak bunun sebebinin, yeterli personel istihdam edilmediğinden, bilgi ve beceri eksikliği ile yeterli işletme kabiliyetinin olmadığından kaynaklandığı söylenebilir.

Soru 8: Arazi toplulaştırması; parçalı, dağınık ve şekilleri bozuk arazi parçalarının uygun biçimde düzenlemesi, yol, sulama, drenaj, arazi tesviyesi, toprak korunması ve 1slahı gibi hizmetlerin yanı sıra çok sayıda faydaya sahiptir (Akkaya-Aslan ve Arıcı 2010). Bundan dolayı arazi toplulaştırması, sulama birliklerinin yönetim organizasyonlarının sağlıklı yürümesine önemli katkı sağlamaktadır. $\mathrm{Bu}$ nedenle çiftçilere arazi toplulaştırması ile ilgili arazi toplulaştırılmasını isteme durumları hakkında soru yöneltilmiştir. Genel olarak çiftçilerin büyük çoğunluğunun arazi toplulaştırmasını istemedikleri (\%63) görülmektedir. Burada özellikle; arazi toplulaştırmasına çok az evet diyen İznik Merkez (\%15), Bursa (\%16), İznik Ova Köyleri (\%19), Demirtaş (\%20) ve İznik Gölü Keramet (\%21) sulama birlikleri dikkati çekmektedir. Düşük değerlere sahip bu bölgelerde yetiştirilen ürünler ağırlıklı olarak; zeytin, armut, şeftali, incir, elma gibi meyve ağaçları oluşturmaktadır. Çiftçilerin meyve ağaçlarını taşıma durumunun olmadığını düşünmeleri sebebiyle arazi toplulaştırma isteme oranı da düşük olmuştur. Yüksek oranlara sahip sulama birliklerinde ise tarımsal faaliyeti ağıllıklı olarak tek yıllık bitkilerin oluşturduğu ve çiftçilerin çoğunlukla arazi toplulaştırmanın faydalarından yararlanmak istedikleri görülmektedir. Genel anlamda, arazi toplulaştırmasına olumlu bakan çiftçilerin olduğu alanların bazılarında daha önceki dönemlerde ya toplulaştırma gerçekleştiği ya da parsel büyüklüklerinin faydalarını görmüş olmalarından kaynaklandığı söylenebilir. 
ÇOMÜ Zir. Fak. Derg. (COMU J. Agric. Fac.)

2020: 8 (1): 213-224

ISSN: 2147-8384 / e-ISSN: 2564-6826

doi: 10.33202/comuagri. 703518

Çizelge 6. Çiftçiler ile yapılan anketlere ilişkin sonuçlar (\%)

\begin{tabular}{|c|c|c|c|c|c|c|c|c|c|c|c|c|}
\hline $\begin{array}{c}\text { Soru } \\
\text { No }\end{array}$ & Soru & $\begin{array}{c}\text { İznik Gölü } \\
\text { Keramet }\end{array}$ & $\begin{array}{c}\text { İznik Ova } \\
\text { Köyleri }\end{array}$ & $\begin{array}{c}\text { İznik } \\
\text { Merkez } \\
\end{array}$ & Karacabey & Uluabat & Mustafakemalpaşa & Yenişehir & Bursa & Demirtaş & Nilüfer & Ortalama \\
\hline 1 & $\begin{array}{l}\text { Sulanan Bitkinin Su Tüketimi } \\
\text { Konusundaki Bilgi Düzeyi }\end{array}$ & 41 & 39 & 45 & 44 & 40 & 42 & 45 & 39 & 37 & 41 & 41 \\
\hline 2 & $\begin{array}{l}\text { Kullanılan Sulama Yöntemi Konusunda } \\
\text { Bilgi Düzeyi }\end{array}$ & 61 & 65 & 62 & 68 & 63 & 66 & 64 & 66 & 62 & 61 & 64 \\
\hline 3 & $\begin{array}{l}\text { Su Kullanıcılarının Sulama Konusunda } \\
\text { Eğitim Alma Durumu }\end{array}$ & 5 & 2 & 4 & 3 & 4 & 5 & 2 & 3 & 4 & 5 & 4 \\
\hline 4 & $\begin{array}{l}\text { Çiftçilerin Sulama Faaliyetlerini Bilinçli } \\
\text { Olarak Yapma Konusundaki } \\
\text { Düşünceleri }\end{array}$ & 66 & 62 & 63 & 71 & 69 & 66 & 65 & 58 & 59 & 60 & 64 \\
\hline 5 & $\begin{array}{l}\text { Sulama Suyunun Zamanında ve Yeterli } \\
\text { Miktarda Alınması Konusunda Çiftçi } \\
\text { Düşünceleri }\end{array}$ & 89 & 85 & 87 & 84 & 45 & 86 & 83 & 65 & 46 & 79 & 75 \\
\hline 6 & $\begin{array}{l}\text { Su Kullanıcılarının Sulama Suyu Ücreti } \\
\text { Konusunda Düşünceleri }\end{array}$ & 91 & 89 & 88 & 76 & 68 & 75 & 76 & 77 & 87 & 74 & 80 \\
\hline 7 & $\begin{array}{l}\text { Birlik Personelinin Sulama Tesislerini } \\
\text { Denetleme Konusundaki Çiftçi } \\
\text { Görüşleri } \\
\end{array}$ & 88 & 85 & 87 & 90 & 65 & 91 & 79 & 75 & 55 & 74 & 79 \\
\hline 8 & $\begin{array}{l}\text { Çiftçilerin Arazi Toplulaştırmasına } \\
\text { Bakışı }\end{array}$ & 21 & 19 & 15 & 67 & 65 & 56 & 48 & 16 & 20 & 45 & 37 \\
\hline 9 & $\begin{array}{l}\text { Sulama Birliği'nin Su Dağıtım Programı } \\
\text { Konusundaki Çiftçi Görüşleri }\end{array}$ & 90 & 89 & 91 & 88 & 56 & 91 & 68 & 72 & 52 & 76 & 77 \\
\hline 10 & $\begin{array}{l}\text { Sulama Hizmetlerinden Tüm Su } \\
\text { Kullanıcılarının Eşit Oranda } \\
\text { Yararlanabilme Durumu Konusunda } \\
\text { Çiftçi Görüşleri } \\
\end{array}$ & 88 & 89 & 86 & 87 & 63 & 91 & 73 & 63 & 51 & 74 & 77 \\
\hline 11 & $\begin{array}{l}\text { Sulama Birliği Tarafından Yapılan } \\
\text { Bakım Onarım Çalışmalarının } \\
\text { Yeterliliği Konusunda Çiftçi Görüşleri } \\
\end{array}$ & 91 & 90 & 87 & 89 & 48 & 91 & 76 & 67 & 48 & 77 & 76 \\
\hline 12 & $\begin{array}{l}\text { Sulama Birliği'nde Çalışan Personel } \\
\text { Sayısının Yeterliliği Konusundaki } \\
\text { Görüşler }\end{array}$ & 95 & 91 & 90 & 91 & 51 & 92 & 88 & 74 & 39 & 81 & 79 \\
\hline 13 & $\begin{array}{l}\text { Sulama Birliği'nin Hizmetlerinden } \\
\text { Çiftçilerin Memnuniyet Düzeyleri }\end{array}$ & 94 & 93 & 90 & 95 & 44 & 92 & 79 & 72 & 36 & 78 & 77 \\
\hline
\end{tabular}


Soru 9: Sulama birliklerinin uyguladıkları su dağıtım programlarının yeterli olma durumuyla ilgili yapılan anketin sonuçlarına göre, su dağıtım programının yeterli olduğunu düşünenlerin oranı \%77 bulunmuştur. En yüksek orana sahip sulama birlikleri İznik Merkez (\%91) ve Mustafakemalpaşa (\%91) iken, en düşük Demirtaş (\%52) ve Uluabat (\%56) sulama birlikleri olarak belirlenmiştir. Düşük değerlerin elde edilmesinin temelinde; organizasyon yetersizliğinin, tesislerde bakım onarım ve izleme değerlendirmedeki noksanlıkların olduğu düşünülmektedir. Planlı bir sulamanın gerçekleştirilmesi için çiftçilerin sulama birliği tarafında uygun görülen zamanda ve miktarda sulama yapması sağlanmalıdır. Açık kanal şeklinde olan tesislerde çiftçilerin kanallarda su olduğu zaman istedikleri anda suyu kullanmalarının önüne geçilmelidir. Bu durum, kanal başında olan çiftçilere üstünlük sağlarken kanal sonundaki çiftçilerin zamanında sulama yapamama sorununu ortaya çıkarmaktadır. Burada işletme tarafından uygulanması gereken izleme değerlendirmenin ve işletme becerisinin geliştirilmesi önemi bir kez daha ortaya çıkmaktadır.

Soru 10: Burada, tüm su kullanıcılarının sulama hizmetlerinden eşit oranda yararlanabilme durumu çiftçilere sorulmuştur. Burada öncelikle su kaynağına ve iletim kanallarına yakın olan parsellerin suya erişmesi daha kolayken, kanalların sonlarında ve uzak olan parsellerdeki çiftçilerin suya erişmesi bazı zamanlarda zor olabilmektedir. Buna göre çiftçilerin vermiş oldukları cevaplar incelendiğinde, Demirtaş S.B.'ne bağlı çiftçilerin sadece yarısı (\%51) suya ulaşabildiklerini belirtmişlerdir. Ortalamanın altında olan birliklerde, bu değerlerin düşük olmasının başlica sebeplerinin; bakım onarım yetersizliğinden dolayı zamanla kanal sonlarına sulama suyunun ulaştırılamaması, sulama planlarının uygulanamaması ve çiftçinin tesise müdahale etmesi olduğu söylenebilir.

Soru 11: Sulama birliklerinin; işletme sahasındaki su iletim dağıtım kanallarında meydana gelen tahribatların onarımı ve bakımı, kanalların çevresinde ve içerisinde oluşan yabancı otların temizlenmesi ve ilaçlanması, pompaj sulamalarda pompaların bakım onarımı, servis yollarının düzenlenmesi, kullanmakta oldukları araç ve ekipmanların bakım onarımı gibi başlıca sorunların tespiti ve bu sorunların giderilmesini sağlayarak tesisin ve işletmenin bir sonraki sulama sezonuna hazırlaması gerekmektedir. Bu nedenle çiftçilerin; sulama birliği tarafından yapılan bakım onarım çalışmalarını yeterli bulma durumları sorulmuştur. Verilen cevaplara göre, bakım onarım çalışmalarının çiftçiler tarafından yeterli bulunma oranının en düşük olduğu birlikler Uluabat (\%48) ve Demirtaş (\%48) olarak belirlenmiştir. Yeterlilik oranlarının düşük olmasında, yeterli nitelikte personelin olmaması, ekonomik alım gücü yetersizliğinden dolayı bakım onarım için yeterli mal ve malzeme alınamaması gibi başlıca sebeplerin olduğu söylenebilir. Ortalama değer dikkate alındığında birliklerin önemli bir kısmının ortalamanın üzerinde olduğu görülmektedir. Bu da birliklerin bakım onarım çalışmalarından genel olarak memnun olunduğu sonucunu çıkarmaktadır.

Soru 12: Sulama birlikleri; sulama alanının büyüklüğü, sulama tesisinin özellikleri, kullanılan araç ve gereçlerin çeşitliliği gibi nedenlerle çeşitli mesleklerde istihdam sağlamaktadır. Bunlar başlıca; genel sekreter (birlik müdürü), sayman (muhasebe), tahsildar, sulama görevlisi, iş makinası operatörü, şoför, elektrik teknikeri-teknisyeni, makine teknikeri-teknisyeni ve büro işçisidir. Çiftçilere, sulama birliklerinde çalışan personel sayısının yeterli miktarda ve yeterli bilgi beceriye sahip olup olmadıkları hakkında görüşleri sorularak elde edilen sonuçlara göre, sulama birliklerinde yeterlilik düzeyi en yüksek İznik Gölü Keramet (\%95) ve en düşük Demirtaş (\%39) sulama birliklerinde olduğu görülmüştür. Demirtaş S.B.'de söz konusu değerin düşük olmasındaki en temel sebebin, sulama birliğinin mevcut personelden daha fazla personel istihdam edebilecek gücünün olmamasından kaynaklı olduğu düşünülmektedir.

Soru 13: Çiftçilere, genel olarak sulama birliğinin yeterli hizmeti sağlama konusundaki düşünceleri sorulmuş ve böylelikle çiftçilerin genel olarak memnuniyet düzeyleri sorgulanmıştır. Verilen cevaplara göre; İznik Gölü Keramet, İznik Ova Köyleri, İznik Merkez, Karacabey ve Mustafakemalpaşa sulama birliklerinde memnuniyet düzeyi oldukça yüksek (\%90 ve üzeri) bulunmuştur. Bunun tersine Demirtaş (\%36) ve Uluabat sulama birliklerinde ise oldukça düşük (\%50'nin altında) sonuçlar elde edilmiştir. Çiftçilerin memnuniyet düzeyinin düşük olmasındaki en temel sebeplerin; sulama hizmet bedelinin yüksek olması, sulama suyuna zamanında ve yeterli miktarda ulaşamaması ve bakım onarım çalışmalarının yetersizliği olduğu düşünülmektedir.

Açık uçlu soru: Çiftçiler ile gerçekleştirilen anket değerlendirmelerinde, son olarak sulamada karşılaştıkları sorunların neler olduğuna dair açık uçlu bir soru yöneltilmiştir. Buna göre, çiftçilerin 
sulamada karşılaştıkları sorunların başında; sulama tesislerinde su kayıplarının fazla olmasından ve kaçak sulama yapan çiftçilerden dolayı kanal sonlarında bulunan çiftçilerin sulama faaliyetlerini yeterli düzeyde gerçekleştirememesi ve bitki su ihtiyacının en yüksek olduğu dönemlerde suya ulaşmakta güçlük çekilmesi gelmektedir. Bazı bölgelerde drenaj yetersizliği sonucu yer yer taban suyu sorununun oluşması, sulama suyu ücretinin yüksek olması, su kaynağına yakın olan çiftçilerin kendilerinden sonraki çiftçinin sulama hakkına saygı duymaması gibi sorunlar bunu takip etmektedir. Ayrıca bazı işletmelerde yönetim ile çiftçiler arasında iletişim eksikliğinden dolayı anlaşmazlıklardan dolayı yer yer huzursuzluklar olduğu da belirtilmiştir.

Farklı alanlarda farklı yıllarda çiftçiler ile yapılan anketlerde de benzer sorunlar dile getirilmiştir. Ceylan ve Gülçubuk (1995) etkin sulamada insan faktörünü inceledikleri çalışmada; etkin ve sürdürülebilir bir sulu tarımın, çiftçilerin eğitimi ve organize olmasına bağlı olduğunu, bakım ve onarımın eksikliğinin tesisten beklenen faydanın sağlanamamasına ve tesislerin kısa sürede işlevini yitirmesine neden olduğunu, sulama tesislerinin bilinçli işletilmemesinin ve sulamaların doğru yapılamamasının sonucunda ise tarım alanlarının tarım toprağı özelliğini kaybedeceğini belirtmişlerdir. Bilgiç (1995) Aşağı Seyhan sulama proje alanında faaliyet gösteren sulama gruplarının çalışmaları ve sorunları çalışmasında: sulama kanallarında yabancı ot ve tortu temizliği yapılması, bakım onarım işlerinin yapılması, suyun etkin kullanımının sağlanması, kaçak sulamaların önlenmesi, sulama ücreti tahsilatı gibi konuları incelemiştir. Karşılaşılan sorunların başında sulama ücretlerinin belirlenmesi ve çiftçilerin sulama ücretlerini zamanında ödeyememeleri gelmektedir. Çalışmanın sonucu olarak, sulayıcı grupların yetki ve yaptırım güçlerinin artırılması önerilmiştir. Beyribey ve ark. (1997) sulama birliklerinde sistem performansının değerlendirilmesi ve katılımcı sulama yönetimine ilişkin çalışmada, fiziki tesislere önem verilmesi yanında sosyal boyutun göz ardı edilmesi sulama sistemlerinde hedeflenen performans düzeyine ulaşılamama nedeni olarak açıklanmıştır. Güvercin ve Boz (2003) yaptıkları çalışmada, bölgedeki çiftçilerin su sıkıntısı çektikleri, çiftçilerin yetiştirdikleri bitkilerin sulama zamanıyla ilgili yeterli bilgiye sahip olmadıkları, çoğunlukla vahşi sulama yöntemlerini kullandıkları, sulama konusundaki kazanımlarının atalarından edindikleri, sulama hakkında herhangi bir eğitim ve yayım etkinliğine katılım sağlamadıkları belirlenmiştir. Şahin ve ark. (2003) araştırmalarında, uygulanan sulama yöntemlerini ve tarımsal faaliyette bulunan üreticilerin sulama ile ilgili alışkanlıklarını belirlemişlerdir. Araştırmaya göre; bölge çiftçisinin yaklaşık \%87'si su kaynaklarının yetersiz olduğunu düşünmekte, buna rağmen çiftçilerin \%51'i sulama yöntemi olarak salma sulama yöntemini tercih etmektedir. Çiftçilerin tamamı, su kayıplarını önleme açısından en ideal yöntemin basınçlı (damla - yağmurlama) sulama yöntemleri olduğunu bilmelerine rağmen, özellikle akaryakıtın pahalı olması sebebiyle çoğu zaman bu yöntemleri kullanmadıklarını belirtmişlerdir. Çiftçilerin \%95'lik kısmı suyun yetersizliğini kaynak yetersizliğine bağlarken, \%5'i ise sulama şebekesinin yetersiz olmasına bağlamaktadır. Demir (2008) Diyarbakır Devegeçidi sulama şebekesinde sulama sorunlarını tespit etmek ve bu sorunlara çözüm bulmak amacıyla yaptığı çalışmada; DSİ etüt ve proje raporları ile çiftçilerle yapılan anket sonuçlarını değerlendirmiştir. Araştırma alanında; su iletim sisteminde tahribat ve bununla ilgili bakım onarım hizmetlerini sahiplenecek bir kuruluşun olmayışı, çiftçilerin sulama yöntemleri konusunda yeterli bilgiye sahip olmamaları, su dağıtımındaki dengesizlik, su kayıplarının yüksek olması gibi sorunlar saptanmıştır. Bu sorunların giderilmesine yönelik çözüm yolları önerilmiştir.

\section{Sulama Birliklerindeki Personeller ile Yapılan Anket Değerlendirmeleri}

Sulama birliklerinde görevli personellerin çalışma şartları ve sulama hizmeti verme konusunda yönetim ve çiftçiler ile karşılaştıkları sorunları belirlemek için sulama birlikleri işletme alanında ve yönetiminde görev alan personeller ile anket yapılmıştır. Anketler, birlik bazında değil tüm birlik çalışanları dikkate alınarak yapılmıştır. Elde edilen sonuçlar, Bursa ilindeki tüm birliklerin ankete katılan çalışanlarının sorulara verdiği cevaplardır.

Çiftçilerin sulama tesisinin korunmasında katkıları konusunda birlik personellerinin görüşleri: Sulama birliği işletme alanında bulunan çiftçiler parsellerinde tarla içi çalışmalarını gerçekleştirirken bazı zamanlarda tarım ekipmanları ile iletim dağıtım tesislerine zarar verebilmektedirler. Meydana gelen tahribat tarım makinası ile kanallara yakın şekilde tarla içi çalışmaları gerçekleştirilmesinden dolayı oluşmaktadır. Ayrıca çiftçiler kanallardan su alabilmek için su alma ekipmanlarını kanalların içerisine bırakmakta, bu işlem sırasında ekipmanlarının su akış hızından etkilenmemesi için alıcılarının etrafına taş, kum torbası gibi ağırlık koymakta ve sulama 
işlemi sonrasında ise kanal içine bıraktığı taşları geri almamaktadır. Kanal içerisinde geri alınmayan taşlar hem su seviyesinin yükselerek kanallarda taşma oluşturmakta hem de sürtünme ile kanallara zarar vermektedir. Nitekim bu bulgular birlik personeline sorulan çiftçilerin sulama tesisinin korunmasında katkıları olup olmadığına ilişkin soruya verilen cevaplardan da anlaşılmaktadır. Sulama birliğinde görev alan personel ile gerçekleştirilen bu anketler sonucunda, personelin \%84'ü çiftçilerin sulama tesislerinin korunmasına katkıda bulunmadıklarını belirtmişlerdir. Çiftçilerin tesisin korunması konusunda katkıda bulunmamaları sonucunda sulama birliklerinin bakım onarım giderleri artmakta ve artan giderler ise yine çiftçilere dönerek sulama hizmet bedellerinin artmasına sebep olmaktadır.

$\mathrm{Bu}$ çerçeve kapsamında; sulama birliklerinin işletme alanında faaliyet gösteren çiftçilerimizde 'her şeyi devlet yapar' düşüncesinin hakim olduğu anlaşılmaktadır. Bu durum, çiftçilerin ücretsiz hizmet alma eğilimlerini ortaya koymaktadır. Çiftçiler için inşa edilmiş olan sulama tesislerinin yine çiftçiler tarafindan korunması gerektiği düşüncesinin ve sulama tesislerinin sahiplenme duygusunun çiftçilere kazandırılmasıyla sulama birliklerinin başarısının olumlu yönde gelişeceği düşünülmektedir.

Sulama birliğinde çalışan personel sayısı ve niteliği ile ilgili personel görüş̧eri: Sulama birliklerinde ofis ve arazi işleri yönünden yeterli sayı ve nitelikte personel istihdamına özen gösterilmelidir. İşletme alanında çalışan personel daha çok beden gücünde ve iş makinası kullanımında görev almaktadır. Ayrıca personeller, çiftçiler ile sahada sürekli yüz yüze oldukları için iletişimin kuvvetli ve karşılaşılan sorunlarda çözüm odaklı olmalıdır. Sulama birliğinde görev alan personellerin \%61'i yeterli sayı ve nitelikte çalışan olduğu düşüncesindedir. Sulama birliklerinde yöreyi bilen ve o bölgede yaşayan kişilerin daha çok tercih edildiği ve bunun da sahada daha faydalı olduğu ifade edilebilir. Bazı sulama birliklerinde fazla sayıda personel istihdam edilirken bazılarında önemli eksiklikler bulunmaktadır.

Personelin sulama ücreti tahsilatı ile ilgili sorun yaşama durumu: Sulama birlikleri, sulama hizmetinden yararlanan çiftçilerden bu hizmete dair bedeli tahsil ederek işletme alanındaki varlığını sürdürmektedirler. İşletmelerde çiftçilerin sulama hizmet bedelini ödemeleri konusunda, erken ödeme indirimi, taksit seçenekleri ve son ödeme süresi aşımı halinde ise gecikme zammı uygulanmaktadır. Personellere, sulama hizmet bedelinin tahsil edilmesi noktasında sorun yaşama durumları sorulduğunda, \%67 oranında sorun yaşandığı belirtilmiştir. Çiftçilerde oluşan algı ağırlıklı olarak suya para ödememektir. Fakat çiftçiler sulama suyuna değil, suyun kaynaktan parsele iletiminin sağlanması ve işletmenin sağladığı hizmet giderlerinin karşılanması için ücret ödemektedirler. Bazı su kullanıcılarında oluşan bu algının yıkılarak benimseme algısı kazandırılmalıdır. Birlikler tarafından sağlanan hizmetlerin zamanla azalması ya da sürekli aynı düzeyde devam etmesinden ziyade hizmet kalitesini ve güncel teknoloji ile modern sulamaların yaygınlaşmasında öncülük edebilmesi için zamanında ödenen sulama suyu ücretleri ve kaçak sulamaların en aza inmesi önem arz etmektedir.

Birliklerdeki personellerin gözlenen diğer sorunlar: Sulama birliğinde görev alan personelin en önemli sorunu, sosyal hak ve sorumluluklarının net olmamasıdır. Sulama birlikleri kamu kurumu olmasına rağmen, personeller özel iş kanununa tabi olduğundan dolayı, çalışanlar bir güvence altında olmadıklarını düşünmektedirler. Çalışma alanında bulunan sulama birliklerinde aynı görevleri üstlenen kişilerin maaş ve iş haklarında farklılıklar olmaktadır. Bu farklılıkların en temel sebebi, sulama birliğinin ekonomik gücü ve yönetim yapısının aldığg kararların her sulama birliğinde farklılık (başkan ve yönetimin maaş ve hak belirlemede karar verici olması gibi) göstermesidir.

Uçan ve Boz (2005) sulama birlikleri personelinin mesleki açıdan yeterliliklerini ele aldığ 1 çalışmasında, birliklerdeki personelin yaşı, kitle iletişiminden yararlanma, sosyal haklar, yakın ve uzak çevreyle olan ilişkiler, eğitim düzeyi, sulama birliği ile çiftçi ilişkileri ve birlik elemanlarının yeterlilik düzeyleri incelenmiş̧tir. Araştırmada, orta yaş grubunun yoğun olduğu, tarım konusundaki eğitimin yetersiz olduğu, kitle iletişiminden yeterince yararlandığı, yakın ve uzak çevresiyle ilişki halinde olduğu, sosyal güvencelerinin düşük olduğu, sulama birliği ile çiftçi ilişkilerinde bazı sorunlar yaşadığı belirlenmiştir. Birlik personelinin en yeterli oldukları konular üreticilerle olan iletişimin güçlü olması, hangi çiftçinin ne zaman sulama yapacağı ve bölgedeki sulama sorunlarının bilinmesi konuları olduğunu belirtmiştir. Kıymaz (2006), sulama birliklerinin sorunları üzerine yaptığı çalışmasında, Gediz Havzası'nda DSİ tarafindan işletilen ve sonrasında birliklere devredilen sulama hizmetlerini karşılaştırılmalı olarak değerlendirmiştir. Sonuç olarak, devredildikten sonra, su kullanımının artış gösterdiği, çiftçilere sulamayla ilgili bir eğitimin ya da yayımın yapılmadığı, üreticilerin sulama tesislerinin korunmasında katkılarının yeterli düzeyde olmadığ belirtilmiştir. Ayrıca, işletmelerde 
bakım onarım için yeterli bütçenin ayrılmadığı, sulama birliklerinin çoğunda ihtiyaç duyulan iş makinalarının olmadığını, birliklerde alet ve makine parkının oluşturulması gerektiği belirtmiştir.

\section{Sonuç ve Öneriler}

Tarımsal faaliyet gösteren bireylerin 46-65 yaş grubu ile ilk ve ortaokul eğitim düzeyinde yoğunlaştığı belirlenmiştir. Genç nüfusun eğitim ve öğretim seviyesi arttıkça tarımsal faaliyet yerine diğer meslek gruplarına ağılık verdiği görülmüştür. Genç ve eğitimli nüfusun tarımdan uzaklaşması, tarımda modern tekniklerin ve yenilikçi çözümlerin uygulanmasını da güçleştirmiştir. Bu nedenle, genç nüfusun tarıma yönelmesi için devlet tarafından uygulanan desteklerin ve teşviklerin daha ağırlık kazanması gerekmektedir.

Çalışma alanının \%32'sinde tamamen yüzey, \%28'inde de yüzey+basınçlı sulama sistemlerinin kullanıldı̆̆ı tespit edilmiştir. Yüzey sulama sistemlerinin kullanılmasındaki sebebin başında, sulama tesislerinin açık kanal/kanalet sistemi olmasından kaynaklandığı görülmüştür. Birçok bölgede yüzey sulama yöntemlerinin yanında yeterli basınç elde edilen tesislerde genellikle hem yüzey hem de basınçlı sistemin beraber kullanılmaya devam edildiği belirlenmiştir. Bunun için inşa edilecek sulama tesislerin kapalı şebeke sistemi şeklinde inşa edilmesi büyük önem arz etmektedir. Sulama birlikleri damla sulama başta olmak üzere su kaybının düşük randımanın yüksek olduğu sulama yöntemlerinin yaygınlaşmasında yayınlar ve teşvikler sağlamalıdır.

Bitki su tüketimi hakkında çiftçilerin kendi kazanımlarının yeterli olduğunu ve sulama zamanını belirlemede bitkinin dış görünüşüne göre karar verildiği belirlenmiştir. Bu konuyla ilgili bilinçlendirme çalışmalarının yapılmasına ihtiyaç vardır. Uygulanan doğru yöntem ile gerçek su tüketimi belirlenerek zamanında ve yeterli miktarda sulama sağlanmalıdır. Çiftçilerin zamanında ve yeterli düzeyde suya ulaşmakta güçlük çektikleri de ele alındığında, sulama işletmelerinin her bir çiftçiye kullanacağı su miktarını ve zamanı reçete şeklinde hazırlayarak uygulama noktasında takibini sağlamalıdır. Doğru yöntemlerin benimsenmesiyle, çiftçilerin zamanında ve yeterli miktarsa suya ulaşmanın güçlüğ̈̈ ve bitki su tüketimindeki yanlış tespitlerin giderileceği düşünülmektedir.

Su kullanıcılarının ödeyeceği sulama suyu ücretlerinin, genellikle yüksek olduğu düşüncesi hakimdir. Fakat işletmelerde enerji ve sigorta başta olmak üzere birçok giderin karşılanması gerekmektedir. Birim sulama ücretinin daha düşük olabilmesi için, sulama oranının arttırılarak daha fazla su kullanıcısına ulaşılmasıyla, giderlerin daha çok kullanıcıya pay edilmesi sağlanacak ve böylece sulama ücretlerinde azalma sağlanabilecektir.

Yeterli personel istihdam edilememesi, yönetimde eksikliklerin olması ve yeterli işletme kabiliyetinin olmaması tesiste denetim eksikliklerine neden olabilmektedir. Tesislerin yeterli düzeyde denetlenmesi, su iletim ve dağıtım kanallarında meydana gelen sorunların erken tespiti ve onarımı, iletim ve dağıtım kanallarında kaçak sulamaların engellenmesi gibi izleme değerlendirme becerisi sağlanmalıdır. Bunun için sulama birliklerinde görevli personeller, izleme ve değerlendirme çalışmaları yaparak tesiste bir denetim mekanizması oluşturmalı ve yönetim tarafından sık sık denetlenerek esneklik oluşumunun önüne geçilmelidir.

Su kaynağına ve iletim dağıtım kanallarına yakın parsellerin çiftçilere avantaj, uzak olanların ise dezavantaj sağladığı tespit edilmiştir. Çiftçilerin, sulama hizmetinden eşit oranda faydalanamamasını genellikle işletme tesisinin bakım onarım yetersizliğinden dolayı zamanla kanal sonlarına sulama suyunun ulaştırılamaması, sulama planlarının uygulanamaması ve çiftçinin tesise müdahale etmesi gibi faktörlerin etkilediği görülmüştür. Bunu önlemek için, tesisin sonlarında bulunan parsellere su kullanım önceliği verilerek su kaynağına doğru kontrollü sulama sağlanması önerilebilir. Ayrıca, sulama sezonunda çiftçinin suya müdahalesi engellenmeli, gerekli durumlarda idari para cezaları ile caydırıcı yöntemler izlenmelidir.

Sulama birliklerinin bir kısmında bakım onarım çalışmaları yeterli olsa da birçok sulama birliğinde önemli eksikliklerin olduğu belirlenmiştir. Bahsi geçen bakım onarım yetersizliklerinde ihtiyaç duyulandan az sayıda ve yeterli nitelikte personelin olmaması, iş makinası ve araç eksikliği, mal ve malzeme alımlarında finansal kaynak yetersizliği gibi başlıca sebepler olarak belirlenmiştir. Bakım onarım çalışmalarının aksamaması ve yeterli olabilmesi için, gerekli ihtiyaçları karşılayabilecek araç ve iş makinası havuzu oluşturularak sulama birliklerinin karşılaştığı bu sorunların giderilebileceği düşünülmektedir. Ayrıca, iş yükü fazla olan bakım onarım çalışmaları için 
alanında uzman kişiler tarafında oluşturulacak şubeler ile bakım onarım çalışmalarını üstlenen birimin daha hızlı ve çözüm odaklı olacağı düşünülmektedir.

Sulama birliklerinde görev alan personeller arasında bazı hak ve sorumluluklarda farkl1liklar olduğu tespit edilmiştir. Bu durumun, farklı sulama birliklerinde çalışan personeller arasında motivasyon eksikliğine sebep olduğu görülmüsstür. Sulama birliklerinde çalışan personeller özel iş kanununa tabi oldukları ve bu durumda iş güvencelerinin olmadığı kaygısını taşımaktadırlar. Tüm sulama birliklerini kapsayacak bazı standartlar getirilip eşit hak ve sorumlulukların oluşturularak uygulanması gerekmektedir.

Not: Bu çalışma, Ömer Tarık ERSÖZ’ün Yüksek Lisans tez çalışmasından hazırlanmıştır.

\section{Kaynaklar}

Akkaya Aslan, Ş.T., Arııı İ., 2010. Arazi Toplulaştırması Planlama ve Projelemesi Ders Kitabı, Bursa, 65-73.

Beyribey, M., Erdoğan, C., Çakmak, B. ve Aküzüm, T., 1997, Katılımcı sulama yönetimi ve sulama birliklerinde sistem performansını değerlendirilmesi. 6. Ulusal Kültürteknik Kongresi, 5-7 Haziran, Bursa, 172-179.

Bilgiç, A., 1995. Aşağı Seyhan sulama proje alanında faaliyet gösteren sulama gruplarının çalışmaları ve sorunları. Çukurova Üniversitesi, Fen Bilimleri Enst., Yüksek Lisans Tezi., Adana.

Ceylan, C., Gülçubuk B., 1995. Etkin sulamada insan unsuru. Tarımda Su Yönetimi ve Çiftçi Katılımı Sempozyumu. TMMOB Zir. Müh. Ankara, 284-292.

Çiftçi, N., Kara M., Uğurlu N., Topak R., 1995. Konya İli sulama kooperatiflerinin sulamadaki yeri ve işletmecilik sorunları. Selçuk Üniversitesi, Zir. Fak. Dergisi, 7 (9): $42-55$.

Demir, N., 2008. Diyarbakır Devegeçidi sulama şebekesinde sulama sorunları. Selçuk Üniversitesi, Fen Bilimleri Enst., Yüksek Lisans Tezi., Konya.

Güvercin, Ö., Boz İ., 2003. Üreticilerin sulu tarım konusundaki deneyimleri ve sulama birliklerine bakışı: Düziçi İlçesi örneği. Kahramanmaraş Sütçü İmam Üniversitesi, Fen ve Müh. Derg., 6 (2):80-90.

Kıymaz, S., 2006. Gediz Havzası örneğinde sulama birliklerinin sorunları ve çözüm yolları. Çukurova Üniversitesi, Fen Bilimleri Enst., Doktora Tezi, Adana.

Süheri, S., 2004, Konya ovasında sulama örgütlerinin işletmecilik yönünden karşılaştırılması. Selçuk Üniversitesi, Fen Bil. Ens., Yüksek Lisans Tezi, Konya.

Sivük, H., 2010. Konya Ereğli İvriz sağ sahil sulama birliği üyelerinin su kullanım davranışları üzerine bir araştırma. Ankara Üniversitesi, Fen Bilimleri Enst., Doktora Tezi, Ankara.

Şahin, M., Oğuz C., Arısoy H., Yılmaz A.M., 2003. Konya İli Çumra İlçesi’nde uygulanan sulama yöntemlerinin tarımsal yayım açısından değerlendirilmesi. II. Ulusal Sulama Kongresi Bildiri Kitabı. 16-19 Ekim Aydin, 409-417.

Uçan, K., Boz, İ., 2005. Sulama birlikleri personelinin mesleki açıdan yeterlilikleri: Kahramanmaraş İli Örneği. Atatürk Üniv. Ziraat Fak. Derg. 36 (1), 69-75. 